\title{
A lógica pastoral na prática docente
}

\author{
Estela Scheinvar, ${ }^{\star \star}$ Rebecca Medeiros, Patrick Coutinho \\ Universidade do Estado do Rio de Janeiro, Rio de Janeiro, RJ, Brasil
}

Resumo

O presente texto apresenta uma pesquisa conceitual e o seu diálogo com as práticas cotidianas da escola, tendo como foco a lógica pastoral na prática docente. Como trabalho de campo foi realizado um curso de extensão para trabalhadores da escola e estudantes de formação de professores, tendo como tema "crises e conflitos na escola". Ferramentas conceituais foram apresentadas, atividades plásticas realizadas e debates provocados, abordando o poder pastoral e a produção subjetiva construida na sociedade liberal tendo como foco o trabalho docente. Em contraste com a realidade atual emergiu na fala dos professores a força coativa de personagens romanceados que produzem uma certa identidade de professora. As cenas apresentadas pelos participantes desta experiência de pesquisa deixam claros atravessamentos no cotidiano escolar das políticas e dos projetos pedagógicos em curso, bem como a importância de construir espaços coletivos para pensar os sentidos do fazer pedagógico na escola.

Palavras-chave: poder pastoral; escola; prática docente.

\section{Teaching under the logic of the pastoral power}

\begin{abstract}
The present text presents a conceptual research, and its dialogue with the school everyday practice, having as goal the experience of teaching under the logic of the pastoral power. As a field work we organized an extension course aimed at school workers and teachers-to-be, round the theme "crises and conflicts at school". Conceptual tools were presented, plastic activities done and debates provoked, approaching the pastoral power and the subjective production constructed in the liberal society, in a relation with the work of teaching. Contrasting the present reality, emerged in the voice of some teachers the coactive force of romanticized characters presented in movies and television programs that produce a certain identity of a woman-teacher. The scenes presented by the participants of this experience make clear the crossing of the pedagogical policies with the projects developed in school, as well as the importance of constructing collective spaces to think the senses of the pedagogical labor at school.
\end{abstract}

Keywords: pastoral power; school; practice of teaching

\section{O professor e suas ovelhas}

Nos dias 17, 18 e 19 de julho de 2013 realizamos, na Faculdade de Formação de Professores de São Gonçalo da Universidade do Estado do Rio de Janeiro, um curso de extensão denominado "Pensando ferramentas para intervir em conflitos e crises na escola". Destinado a professores e demais profissionais atuantes no espaço escolar, bem como a estudantes universitários, ele foi organizado e ministrado por um grupo de pesquisa que vem estudando a lógica penal e os seus atravessamentos nas práticas ditas de garantia de direitos. $\mathrm{O}$ objetivo do curso era problematizar as tensões do cotidiano escolar, a partir de um referencial conceitual apoiado nas ideias de Michel Foucault e, para tanto, foram trabalhados os seguintes temas: mecanismos disciplinares, campos de força que atravessam a escola, processos de normalização, lógica penal e universalização da escola. A análise dos debates do curso nos levou a escrever este texto, destacando apenas algumas das muitas preocupações e problematizações que emergiram nesse espaço de pensamento coletivo.

Podemos dizer que as falas dos participantes do curso mostraram como preocupação central a relação que os professores estabelecem com os estudantes. A partir de suas experiências entendem ser a relação professor-aluno a responsável pelo sucesso no processo de escolarização:

\footnotetext{
^Apoio: FAPERJ/CNPq/UERJ.

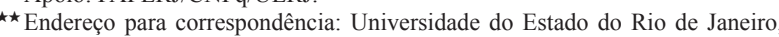
Faculdade de Formação de Professores. Rua Francisco Portela 794 - Paraíso São Gonçalo, RJ - Brasil. - Caixa-postal: 24435005.E-mail: estelascheinvar@ gmail.com, rebecca.mdrs@gmail.com,patrick_saqua@hotmail.com
}

Isso que eu me pergunto todo santo dia. O que eu tô fazendo dentro da sala de aula? E o que que tem, qual é, não digo nem a questão do compromisso em si, mas o que é aquela relação professor-aluno? Eu me sinto muito culpada às vezes, eu entro muito em conflito. Até onde eu estou sendo responsável em matar a vontade de viver daquelas crianças? Até onde eu tô tirando isso? E até onde eu tô alimentando? Então assim, todo dia eu acordo e penso, no ônibus [eu penso], eu durmo pensando, isso vai me enlouquecer, acho que sim, vai chegar um momento que isso vai ser mais forte do que eu (Professora 1).

O comportamento do professor, as possibilidades de ele criar vínculos com os estudantes, a sua capacidade de fazê-los interessar-se pelos conteúdos e de apreendêlos foram elementos entendidos por muitos dos participantes do curso como definidores do futuro dos estudantes. Chamou a nossa atenção a pouca relação que se estabelecia entre esse sentimento e as condições em que se trabalha na escola. Tanto as condições docentes, quanto a lógica pedagógica e os recursos com os que trabalham eram abordados de modo dissociado desse sentimento de enorme responsabilidade por salvar os estudantes, sobretudo os pobres, questionando a sua ética profissional sem mencionar, ao referir-se a ela, à estrutura escolar e às políticas do campo da educação. Tal perspectiva analítica pode ser colocada em análise a partir do célebre curso ministrado no ano de 1978 por Foucault (2008) no Collège de France, "Segurança, Território e População". 
Em sua obra, Foucault afirma que o pastor tem em sua prática uma perspectiva salvacionista. Para ele, o ato de pastorear tem como foco os indivíduos (no nosso caso, os estudantes) e não o território (no nosso caso, a escola), visando o zelo e a salvação das ovelhas. "O poder pastoral é um poder de cuidado. Ele cuida do rebanho, cuida dos indivíduos do rebanho, zela para que as ovelhas não sofram, vai buscar as que se desgarraram, cuida das que estão feridas" (FOUCAULT, 2008 p. 170). Tais características se fizeram presentes nos debates do curso, e podem ser ilustradas com a preocupação de uma professora por formar indivíduos e, mais do que isso, indivíduos que sejam capazes de, por si só, "seguirem caminhos":

Mas nós estamos aqui para produzir, para formar, ajudar a formar indivíduos. Pessoas que dai serão capazes de continuar seguindo o caminho, independente de ser rede pública ou rede privada. Nós, no espaço escolar, estamos aqui pra ajudar a construir indivíduos, capazes de seguir seu caminho... Então nós temos que fazer o melhor, e fazer esse melhor está me colocando em crise [...] (Professora 2).

Segundo o filósofo francês, o poder pastoral não possui raízes helênicas. ${ }^{1}$ Ele emerge no Oriente précristão, sobretudo entre os hebreus. Para Foucault (2008, p. 167), Platão distanciava-se da ideia do homem político como pastor, à diferença da cultura hebraica, para a qual o pastor era essencialmente Deus: “As relações entre Deus e seu povo é que são definidas como relações entre um pastor e seu rebanho. Nenhum rei hebreu, com exceção de David, fundador da monarquia, é nominalmente, explicitamente, designado como pastor". A ideia de pastorado chega ao Ocidente por meio da institucionalização da Igreja Católica, nos séculos II e III depois de Cristo. Será ela a responsável por coagular as relações pastorais em mecanismos e instituições, organizando assim, no seio do Império Romano, essa noção de poder alheia à tradição helênica:

[...] o pastorado começa com certo processo que, este sim, é absolutamente único na história e de que sem dúvida não encontramos nenhum exemplo em nenhuma outra civilização: processo pelo qual uma religião, uma comunidade religiosa se constituiu como Igreja, isto é, como uma instituição que aspira ao governo dos homens em sua vida cotidiana a pretexto de levá-los à vida eterna no outro mundo, e isso na escala não apenas de um grupo definido, não apenas de uma cidade ou de um Estado, mas de toda a humanidade (FOUCAULT, 2008, p. 196).

O poder pastoral que chega ao Ocidente no século II irá manter-se, aperfeiçoar-se, desenvolver-se até o século XVIII, quando temos a emergência da biopolítica, uma tecnologia política das populações. Tal mecanismo, que encontra seu sentido a partir da formação do Estado liberal $^{2}$ e da percepção da população enquanto novo corpo político, visa incluir em um cálculo de poder

\footnotetext{
'Empregamos o termo "helênicas" ao invés de "helenísticas" para fazer referência unicamente à cultura grega clássica, e não ao momento posterior de sua difusão pela região do mediterrâneo, oriente próximo e o norte africano.

${ }^{2} \mathrm{O}$ Estado Liberal baseado no liberalismo econômico é constituído a partir de princípios e teorias políticas, fundamentados na liberdade jurídica e na individualização do sujeito. De acordo com a teoria liberal, o Estado não deve atuar fortemente na economia e na vida cotidiana da população.
}

"características biológicas fundamentais" (FOUCAULT, 2008, p. 3) do homem e fenômenos da vida humana, no intuito de articulá-los nas práticas de controle. Para tanto, será necessário fazer a vida por meio de um processo contínuo de normalização e regulação.

Encontramos no processo de normalização uma ligação entre o biopoder ${ }^{3}$ e o poder disciplinar, que operam pela lógica biopolítica. Ou seja, a norma é essencial tanto para disciplinar um corpo, quanto para a regulação da população, o novo alvo político de governabilidade a partir do século XVIII. Compreendemos que a emergência de uma nova tecnologia de poder, a biopolítica, não substitui tecnologias anteriores, como o poder pastoral. Ao contrário, ambos operam de forma articulada. O poder pastoral passa a interagir com o dispositivo disciplinar, auxiliando-o nos enquadramentos normalizadores, tão importantes ao governo das populações.

Destacamos que, em meio à emergência das novas tecnologias, o poder pastoral não irá extinguir-se, ao contrário, irá manter-se de modo naturalizado nas práticas pedagógicas, prevalecendo a ideia que, como afirma a professora 2, os professores são responsáveis por "[...] ajudar a construir indivíduos, capazes de seguir seu caminho [...]". Entendemos que, atravessada pela relação estabelecida entre disciplina e biopolítica, a articulação do poder pastoral com o poder disciplinar tem sido o modo por meio do qual a escola tem funcionado.

\section{Um pastor disciplinado e flexível}

"Eu exijo que meus alunos fiquem sentados e mantenham a boca fechada, porque preciso dar aquele conteúdo, inserir aquela matéria, apresentar aquele programa, porque se não vou ser cobrada" (Professora 3). A professora deixa claro que só pode cumprir com o que o sistema escolar exige disciplinando seus alunos. Exigir que fiquem em silêncio e devidamente sentados é uma condição para que consiga corresponder ao que é entendido como trabalho de um professor. A docilidade deles e dela ao obedecerem ao que se institui como prática escolar é a expressão do aumento da submissão política e da potência produtiva (econômica) do corpo, como explica Foucault (1987) em seu livro Vigiar e Punir. Nele o autor apresenta de uma maneira ampla a definição de poder disciplinar, constituído por mecanismos de controle do corpo, tornando-o obediente e útil, com o objetivo de produzir indivíduos potentes, capazes de funcionar em uma sociedade concebida como uma máquina. "A disciplina fabrica assim corpos submissos e exercitados, corpos 'dóceis" (FOUCAULT, 1987, p. 119). A construção da docilidade se dá por meio de métodos que se aplicam sobre o tempo, os espaços e as ações, enquadrando a todos.

As equipes pedagógicas usam métodos disciplinares para que todos os que habitam a escola se enquadrem em um padrão de comportamento. Usam técnicas que irão delimitar o que o aluno pode ou não pode fazer

\footnotetext{
${ }^{3} \mathrm{O}$ biopoder, conforme apresentado por Michel Foucault (2008), é um mecanismo de poder integrante da tecnologia biopolítica, que focaliza a população, por meio da organização e ordenação da vida, operando no nível biológico, tendo como centralidade o homem-espécie.
} 
- hora de ir ao banheiro, levantar a mão para falar, manter-se em silêncio, não levantar durante a aula sem a sua autorização, comer a quantidade estipulada de merenda, entre outros. Também os trabalhadores têm que enquadrar-se nas normas: hora de ir ao banheiro, modo de se relacionar com os estudantes e colegas de trabalho, roupa que devem usar... Não bastassem as inúmeras demandas comportamentais e acadêmicas, a equipe pedagógica deve obediência às regulamentações, planos, políticas, regras, programas, enfim, a toda uma estrutura político-pedagógica que define o que ele tem que fazer, em que tempo, de que modo e, o que é mais violento, as metas ou resultados a que tem que chegar. A singularidade daqueles que constroem a relação pedagógica dissolve-se ante o arsenal de ditames aos que todos têm que obedecer.

Embora as resistências coexistam com as estratégias de controle, as normas, como mecanismo articulador da vida coletiva, são produzidas como necessárias ao funcionamento de um espaço esquadrinhado, e boa parte delas são acordadas pelas equipes pedagógicas das escolas, estipuladas e mantidas por elas, definindo e aplicando punições àqueles que não as respeitem - sejam trabalhadores ou estudantes -, afirmando concepções que há séculos vêm se consolidando.

De acordo com os relatos dos presentes ao curso, o uso de fichas de ocorrência como forma de punir os alunos é frequente: "[...] eu uso dessas fichas para a mudança do aluno [de escola]. Se ele tem algum problema [...] é usada como um mecanismo de punição e de vigilância" (professora 4). Nessas fichas os professores relatam os problemas ocorridos em sala de aula - geralmente o mau comportamento dos alunos - à direção, à coordenadora da escola, ao conselho tutelar ou até à Secretaria de Educação. Caso isso não ocorra, a equipe pedagógica pode ser acusada de omissão e sofrer processos jurídicos, conforme relatado por uma professora que mostra a exigência de punir, tanto por parte dos órgãos educacionais como da família:

A gente é punido, o professor é punido por omissão. Eu estou respondendo ao Ministério Público por isso. A escola foi considerada omissa, a diretora e a supervisora também estão respondendo. A família prestou queixa porque nós não punimos. $O$ aluno foi submetido a piadinhas, vexames e bullying, e a gente só conversou, não puniu ninguém. E deu muito trabalho, ainda está lá o inquérito (Professora 5).

Os professores observam que as fichas de ocorrência não têm o efeito prático que gostariam, porém não deixam de acreditar na lógica penal e no seu instrumento dileto, a punição, para tornar seus alunos obedientes e produtivos. Assim como o professor, todos os que estão na escola estão submetidos a práticas de punição que pautam as relações que atravessam a escola. Como afirma a Professora 5, ela foi submetida a processo jurídico por buscar formas próprias para lidar com o ocorrido em sua sala de aula. Contudo, o que constataram as falas foi a busca por outros meios de punir, seja com o uso de fichas ou de novos mecanismos, mantendo a punição como um recurso pedagógico fundamental. Punir passa a ser o cumprimento de um dever, mesmo quando os professores não percebem, efetivamente, mudanças na relação que pretendem modificar por meio do castigo:

Dificilmente eu mando esses alunos serem registrados no livro de ocorrência, porque eles querem faltar à aula e o pai terá que faltar ao trabalho. Ai, o que eu faço? Engulo seco, tiro a educação física, o recreio [...] vou levando [....] Ai para, até a próxima semana [...], depois começa de novo. É assim que eu passo a semana, me preparando para a próxima. Não resolveu naquela semana, não vai resolver na outra, e vamos continuar angustiados com aquele problema que é real.

Não adianta. A gente perde um tempão porque podia estar fazendo um trabalho efetivo dentro da sala [...] algo que não ocorre, porque a gente tem a burocracia, tem que preencher [as fichas], se acontecer alguma coisa vem o processo. Cadê, o que a escola fez? (Professora 6).

A lógica da punição não é estremecida, mas afirmada quando se acredita que haveria uma forma boa, correta, eficiente de castigar. Novas habilidades e rotinas técnicas são anunciadas como suporte para o bom funcionamento da escola, o que se entende como a possibilidade de melhor controlar os estudantes, ou seja, de melhor punir com mais eficiência para que o professor cumpra com as metas estabelecidas. A lógica punitiva não se altera, ampliam-se as tarefas. Esta ideia se encontra com a ampliação de tarefas que a sociedade flexível prescreve para todas as práticas profissionais, como símbolo de competência e de domínio do mundo do trabalho. No livro A corrosão do caráter, Richard Sennett (2009) apresenta como uma nova lógica de trabalho, no fim do século $\mathrm{XX}$, a "flexibilidade", que trouxe mudanças no íntimo do trabalhador que agora não só tem que se submeter a rotinas fixas, mas a demandas diversas e inesperadas, às que tem que responder com prontidão. Ao analisar a prática docente percebemos que os professores trabalham com diversas turmas, em várias escolas, atendendo demandas que vêm de diferentes campos como o da educação, da saúde, da assistência social, do judiciário e, em alguns casos, com contratos de trabalho precários e temporários. Para o autor essa forma de trabalho faz com que o funcionário construa um vínculo tenso com o seu emprego e não veja mais aquilo como um plano a longo prazo para construir um projeto de vida com seus esforços, promovendo desmotivação e descrença em suas relações de produção. Sente-se uma máquina a responder a metas, sem pensar em sua prática.

$O$ professor é obrigado a pegar 5 turmas de 50 alunos $e$ tem que querer ter boa vontade de trabalhar com todos? E isso é uma questão que também me cansa, o problema ser reduzido à falta de vontade de trabalhar. Não é por falta de vontade, pelo menos eu acho que não (Professora 1).

Para Sennett (2009) a ideia de flexibilidade ${ }^{4}$ está $^{-}$ relacionada às formas do eu, à forma como o indivíduo se molda de acordo com as variáveis. Em sua análise ${ }^{4} \mathrm{O}$ capitalismo flexível reduz as exigências formais e legais no sistema empregatício sob o argumento de desburocratizar e facilitar o processo de contratações. Para o autor o imediatismo do capitalismo flexível, as bases instáveis do sistema econômico não são compatíveis com uma definição solida de caráter, ou ética. 
apresenta as ideias de Adam Smith, economista liberal do século XIX, para quem o controle do ritmo e do tempo de trabalho no capitalismo embrutecia os homens. A tese de Smith consistia em demonstrar que com a expansão do mercado seria necessária maior especialização dos trabalhadores e, portanto, ampla divisão do trabalho. Esta, por sua vez, exigiu uma ordem e uma rotina próprias à produção em série, entendida pelo economista como tenebrosa. De acordo com o pensador, quanto mais se trabalha menos se ganha em termos de conhecimento: o indivíduo se torna uma criatura estúpida e ignorante. Essa rotina passa a ameaçar o que Sennett chama de caráter íntimo do ser humano porque embrutece e reduz a espontaneidade da pessoa, redundando em um progresso material, mas não moral. "Em certo ponto, a rotina tornase auto destrutiva, porque os seres humanos perdem o controle sobre seus próprios esforços; falta de controle sobre o tempo de trabalho significa morte espiritual" (SENNETT, 2009, p. 41).

Sennett percebe que, de acordo com Adam Smith, há forças externas variáveis que promovem o caráter pessoal. Já os teóricos pós Smith buscam identificar essa mudança e pensar como ficar livre dessas forças. O que se vê é que essa nova forma de relação de trabalho não liberta, mas cria novos mecanismos de poder e controle. "Em termos ideais, o comportamento humano flexível deve ter a mesma força tênsil: ser adaptável a circunstâncias variáveis, mas não quebrado por elas [....] As práticas de flexibilidade, porém, concentram-se mais nas forças que dobram as pessoas" (SENNET, 2009 p. 53).

Todos os elementos que comportam a flexibilidade prometem a liberdade, o fim das burocracias, findar com as amarras de um antigo regime, mas tudo isso se mostra enganoso, de acordo com Sennett (2009), que considera que surgiram, com a flexibilidade, novas formas de ser burocrático e de vigiar os funcionários. A ampliação de tarefas tem sido justificada por sua correlação direta com a lógica de controle. Com isso vemos que mesmo com medidas disciplinares novas, as condições de trabalho se mantêm tensas, o professor que de um lado é responsabilizado pelo que acontece em sua sala de aula, pelo outro acaba interiorizando um discurso que o faz sentir-se responsável por tal ambiente de trabalho e educação. Sistematicamente, expressam a sua angústia de ter que "educar" os seus alunos, além de ensinar os conteúdos escolares.

Essa separação entre conteúdo e educação, dentro da lógica disciplinar, significa separar a aprendizagem conteudista da disciplina (docilização). Ou seja, o professor espera que seus alunos cheguem à escola obedientes, assim a família seria a responsável por normalizar a criança antes que entre na escola. Há uma separação entre a ideia de ensinar conteúdos e a prática de normalizar, sem perceber que a escola funciona por meio de mecanismos disciplinares e que conteúdo e disciplina são ensinados simultaneamente. Não por acaso os conteúdos acadêmicos são chamados de disciplinas.
Alguns professores se sentem sobrecarregados com a dinâmica docente, tentando superar dificuldades físicas e culturais, como não ter uma sala de aula adequada, não ter material suficiente, não saber lidar com os campos de interesse dos alunos, com o modo como se dão as suas relações familiares ou, ainda, com a maneira como eles se relacionam: "[...] quando eu vou pra escola eu falo com meus amigos 'eu vou fazer tudo, menos dar aula'. Porque eu chego lá não tem bola, não tem material, ou você é psicólogo, ou é amiguinho do aluno" (Professor 1).

Nesse cenário sentem-se responsáveis pela aprendizagem dos estudantes. Para Sennett a condição no trabalho está diretamente ligada à possibilidade de construir as formas de existência das pessoas. Desta perspectiva caberia perguntar-se como poderia o professor conduzir as almas, em uma lógica pastoral, se as suas relações de trabalho e os modos de existência dos estudantes não são compatíveis com a condução das suas crenças?

Ser um bom indivíduo segundo as lógicas pastorais é conduzir as almas a um bom fim. A partir dessa perspectiva ser um bom professor é ser um bom pastor. Cuidar do íntimo de suas ovelhas é a atribuição de um bom pastor, o que significa grande dedicação e controle minucioso da sua vida, porém com esse sistema flexível o professor tem diversas tarefas, se dispersa e não consegue trabalhar sobre tal lógica, gerando mais esgotamentos e descrença: "Na verdade nós não estamos formando ninguém” (Professora 6).

$\mathrm{O}$ que percebemos na fala dos que participaram do curso de extensão é a potência da lógica pastoral, presente nitidamente na prática do professor. Como dito antes, o pastor por excelência é aquele que cuida de todas as suas ovelhas, lhes oferece todo o suporte possível. Um soberano por si só, não tem essa capacidade, não é ele que fornece comida a seus súditos, quem o faz é o agricultor; não é ele que cuida da saúde de seus súditos, essa tarefa é do médico. Assim sendo, o poder pastoral dentro da cidade só seria possível se realizado em atividades focadas. Nesse sentido, os médicos, os pedagogos, os agricultores e, principalmente, os professores, agem sob a lógica do pastor. Possuem vários rebanhos definidos e agrupados por níveis, por escalas organizadas por idade e de acordo com a avaliação de cada etapa, de cada período escolar; devem fazer todo o possível para cuidar de suas ovelhas sem que nenhuma delas se perca, se desvie do curso programado.

[...] o pastorado no cristianismo deu lugar a toda uma arte de conduzir, de dirigir, de levar, de guiar, de controlar, de manipular os homens, uma arte que tem a função de seguilos e de empurrá-los passo a passo, uma arte que tem a função de encarregar-se dos homens coletiva e individualmente ao longo de toda a vida deles e a cada passo de sua existência (FOUCAULT, 2008, p. 218-219). 


\section{O complexo de "Professora Helena"}

Na contemporaneidade a concepção do bom pastor é incorporada no processo que se conhece como produção capitalística $^{6}$ de desejo. Guattari (GUATTARI; ROLNIK, 1996) considera que no capitalismo temos uma produção subjetiva dos desejos em escala internacional. Uma verdadeira "economia coletiva do desejo" (GUATTARI; ROLNIK, p. 26), de acordo com a qual os modelos universalizados são as produções essenciais para o sistema. O autor destaca que tais produções subjetivas não se encontram apenas no campo representativo, mas aderem a formas fixas de ser, sentir e compreender a dinâmica social e o mundo:

Tais mutações da subjetividade não funcionam apenas no registro das ideologias, mas no próprio coração dos indivíduos, em sua maneira de perceber o mundo, de se articular como tecido urbano, com os processos maquínicos do trabalho, com a ordem social suporte dessas forças produtivas (GUATTARI; ROLNIK, p. 26).

Construiu-se historicamente um arquétipo do que é ser e agir como professor, tendo a ideia do pastorado como um dos pilares principais. Pais, alunos e a própria equipe pedagógica exigem do professor determinadas práticas e condutas que sufocam produções subjetivas que se desviam dos modelos produzidos em torno da profissão docente. Trata-se, portanto, de um agenciamento coletivo de enunciação. Coletivo, pois Guattari (GUATTARI; ROLNIK, 1996, p. 28) compreende que não são agentes individuais os responsáveis pela produção de desejos, já que a subjetividade é "fabricada e modelada no registro do social". É uma produção rizomática de serializações, ou seja, uma produção que não possui um tronco, se elabora de forma simultânea, sem algum ponto de origem (DELEUZE; GUATTARI, 1995). A indagação de uma professora presente no curso coloca em análise esse tipo de enquadramento em subjetividades serializadas: "[...] essa também é uma questão histórica do professor ser sempre aquela pessoa perfeita: professor não pode fumar, professor não pode brigar [...]?" (Professora 1). Guattari (GUATTARI; ROLNIK, 1996, p. 29) percebe que os profissionais ditos "sociais", ou seja, psicólogos, sociólogos, pedagogos, professores, assistentes sociais, entre outros, se encontram em uma "encruzilhada política e micropolítica", pois irão operar por meio dos modelos de subjetivação capitalística, encontrando, entretanto, escapes, processos de singularização. ${ }^{7}$

\footnotetext{
Referência à personagem da telenovela "Carrossel", uma adaptação de Iris Abravanel produzida pelo Sistema Brasileiro de Televisão (SBT), da telenovela mexicana "Carrusel".

${ }^{6} \mathrm{O}$ conceito capitalístico, encontrado em Guattari e Rolnik (1996), é usado para frisar as produções subjetivas em sociedades compreendidas como capitalistas, sendo que o processo de produção de desejo não é exclusivo das mesmas, podendo ser encontrado em demais tipos de sociedades.

De acordo com Guattari (GUATTARI; ROLNIK, 1996, p. 16-17): “[...] é possível desenvolver modos de subjetivação singulares, aquilo que poderíamos chamar de 'processos de singularização', uma maneira de recusar esses modos de codificação preestabelecidos, todos esses modos de manipulação e tele comando, recusá-los para construir, de certa forma, modos de sensibilidade, modos de relação com o outro, modos de produção, modos de criatividade que produzam uma subjetividade singular. Uma singularização existencial que coincida com um desejo, com um gosto de viver, com uma vontade de construir o mundo no qual nos encontramos, com a instauração de dispositivos para mudar os tipos de sociedade, os tipos de valores que não são os nossos".
}

Compreendemos, no discurso da professora recém citada, um conflito gerado pela chamada "encruzilhada política". Ela coloca em análise o agenciamento coletivo de enunciação que enquadra suas práticas pedagógicas e pressiona suas subjetividades:

É muito sério porque você como professora, você tem a sua subjetividade, você não pode colocar isso dentro de sala de aula, você não pode ter o seu jeito de ser professora, porque senão os pais vão se decepcionar, a direção vai se decepcionar e as crianças ficam assim: 'Não acredito, professora. Por que você fez isso? [...] a professora Helena jamais faria isso' (Professora 1).

Ela percebe que os agenciamentos em questão não são individuais, pois que difusos no corpo social. Uma produção de individualidades cuja propagação, de acordo com Guattari, se da também por aparelhos midiáticos. No exemplo, a professora apresenta com ironia a produção de um estereótipo da docente perfeita, veiculado em uma telenovela. A "Professora Helena" representa na trama a concepção de professor/pastor: incondicionalmente dedicada ao seu ofício, atenta a todos seus estudantes, elegante, disposta a bem conduzir cada um deles no espaço escolar e no privado. Em face às adversidades a personagem redobra sua dedicação como receita para o sucesso docente. Neste mesmo sentido, uma das participantes do curso que nunca foi professora percebe que: "[...] o que muda, o que pode fazer uma diferença na vida do aluno e do profissional é realmente o amor à profissão [...] Então é questão de ter esperança, é questão de perseverança, é questão de acreditar naquilo que você faz" (estudante de formação de professores 1).

O professor carrega no seu ofício o sacerdócio, se responsabiliza por suas ovelhas de modo a se preocupar com cada uma, a tratá-las individualmente para que o coletivo também seja resgatado dos caminhos inadequados e salvo. Dessa perspectiva, mesmo que tal missão pareça impossível ou desgastante, o professor deve manter a crença de ser o responsável pela salvação de seus alunos. Uma ovelha desviada e perdida significa o fracasso da missão do pastor. Mais do que isto: a afetividade do professor é colocada em questão se entendido que o amor é o que define a sua capacidade profissional.

A fala de uma professora questiona até que ponto os problemas da escola estão relacionados com o amor do professor à sua profissão e aos seus alunos. Socialmente construída, a figura do bom professor, daquele que irá indicar o caminho certo, vem sendo reforçada pela mídia por meio de personagens como a "professora Helena" ou a "professora Maluquinha", ${ }^{8}$ dentre tantas outras produções subjetivas referentes às práticas do magistério. Os agenciamentos que sufocam as resistências a certo modo de subjetivação dos docentes geram incômodo em professoras que questionam a culpabilização a que são submetidas por não seguirem os modelos instituídos:

\footnotetext{
8 "Uma Professora Muito Maluquinha" é um livro escrito por Ziraldo em 1995, cujo personagem central é uma professora bonita, elegante, alegre, jovem, transgressora, mediadora de todos os conflitos familiares de seus estudantes, de grande competência pedagógica e idolatrada por seus estudantes.
} 
[...] isso é uma coisa que tem me incomodado bastante na escola: a gente pensar que às vezes essa questão da incapacidade, dos problemas é a falta de compromisso do professor. [...] Às vezes o professor tem, pode ter toda a boa vontade do mundo, ele pode querer e não vai [conseguir] porque existem outras coisas bem maiores. Na fala dela [referindo-se à colega que pede amor aos estudantes] isso fica bem marcado (Professora 1).

Foucault nos mostra que o poder pastoral é um poder de cuidado. Portanto, para cuidar e auxiliar cada uma de suas ovelhas é necessário individualizar o rebanho, tratar dos problemas específicos de cada um de seus componentes. Nesse sentido, para que o professor/pastor tenha como tarefa um olhar mais próximo para com o aluno, é necessário que atente à intimidade dos discentes, a fim de descobrir possíveis elementos que poderiam desviá-los da conduta considerada correta. Deveriam agir como a romântica professora Helena, que ao desconfiar que algo errado acontecia com suas ovelhas, se dedicava a procurar, sem poupar esforços, as consideradas causas do problema e encontrava sempre a solução a ser aplicada.

Em meio a um sistema econômico que produz subjetividades serializadas em escala global, o não enquadramento nos modelos produzidos cria uma teia de culpabilizações coletivas. Os professores culpabilizam os estudantes, suas famílias, a própria escola, o Estado e são por todos estes culpabilizados. Nessa direção percebemos na fala de uma das professoras que participou do curso a naturalização de tal lógica, quando atribui os problemas pedagógicos às formas de relacionar-se das famílias pobres:

[...] e aquele professor que tem assim, uma escuta mais sensivel né, um olhar mais próximo do aluno, ele acaba chegando a várias conclusões do porquê aquele aluno esta sendo considerado o aluno problema pela escola ou por que aquele aluno não passa de série ou por que aquele aluno tem dificuldade, tem que ser mandado pra sala de recursos, tem que ser mandado pra sala multifuncional, psicólogos, médicos, uma série de coisas. E quando se chega próximo à realidade daquele aluno, se descobre que foi uma aluna que foi violentada com 9, 10 anos, sexualmente, um aluno que sabe que o pai vende drogas, a mãe que diz pra ele "Olha eu só estou com fulano de tal [...]"-que só está com outro companheiro pra não passar fome; "eu não sou feliz com essa pessoa, então você tem que ir pra escola, você tem que estudar porque eu estou me sacrificando, você tem que se sacrificar também", a ponto de bater na própria criança por conta de certos reveses da vida (Professora 8).

Essa fala apresenta uma enorme preocupação da professora com os seus estudantes, mas o faz em um duplo movimento: desloca os problemas pedagógicos da escola para a família e apresenta um olhar carregado de julgamentos morais em relação aos comportamentos familiares. De acordo com este pensamento, o "aluno problema" é uma consequência direta de uma família entendida como "desestruturada", por ser pobre e suas relações serem descritas como aberrações morais. Podemos pensar na associação da ideia de que em famílias pobres a mãe mora com uma pessoa por necessidade financeira, quando sabemos que este é um dado de realidade em todos os segmentos sócio-econômicos, do mesmo modo que não só mães pobres que passam por agruras perdem a paciência com os seus filhos.

Desqualificam-se as relações familiares quando se insiste em afirmar que boa parte dos estudantes não é educada como deveria pela família, responsável por uma ovelha de difícil pastoreio. Assim sendo, defendese não apenas uma intervenção no próprio ambiente familiar como também um acompanhamento psicológico e médico para que se possa colocar novamente a ovelha no "caminho correto". Para pastorear da forma devida, é necessário que a escola receba os alunos previamente enquadrados, previamente inseridos em um modelo desejado, ou que aceitem os seus desvios, facilitando a adequação às normas.

Nem ao menos se cogita o fato de que a escola, essa instituição que historicamente encarcera e aspira à padronização, não faça sentido ao estudante. Não se compreende a "má conduta" como uma forma de resistência aos enquadramentos normalizadores. As pluralidades culturais, as subjetividades múltiplas, não têm espaço no ambiente escolar.

A demanda por um comportamento normalizado não se dá apenas do professor para o estudante, é uma demanda que atravessa todos os que vivem o espaço escolar. As exigências quanto à conduta, aos valores, aos desejos, estão colocadas como condição para a prática docente. A exigência de certo modo de vida não é apenas para os estudantes e suas famílias. É uma condição para a prática pedagógica, que atravessa a todos os profissionais considerados aptos ao trabalho na escola quando disciplinarizados e obedientes a uma ordem que dá sentido a todas as experiências construídas em sua vida profissional.

A "professora Helena", com a sua boa vontade - o seu "amor"-, recusa os modos de existência dos estudantes ao julgar as suas práticas a partir de um padrão moral, aliando-se a eles inclusive para intervir nas famílias. A trama televisiva apresenta a condenação às práticas consideradas desordeiras, seja dos estudantes ou de suas famílias, como uma grande devoção de afeto, que espera-se que seja retribuída com respostas docilizadas, afirmando a relação pedagógica como uma relação de obediência O ideal "professora Helena" se encontra em um paradoxo: esforça-se para bem formar os estudantes e levá-los a um "futuro melhor" por amor, mas para isso é necessário que se condenem as especificidades de cada integrante do rebanho reduzindo-as ao padrão instituído pela escola. Seria a amável professora Helena uma tirana, que decreta não existir caminhos, mas apenas uma única e correta forma, ou seja, "o caminho" que deve ser trilhado por suas ovelhinhas?

\section{O pastorado e a lógica de metas}

Durante todo o curso de extensão foi perceptível certa frustração dos professores em relação às metas estipuladas pelos governos municipais ou estadual, com base no Índice 
de Desenvolvimento da Educação Básica ${ }^{9}$ (IDEB). Em particular, os trabalhadores da cidade do Rio de Janeiro mostraram a enorme pressão que sofrem com a instauração do Prêmio Anual de Desempenho, instituído em 2009. Esse prêmio determina o pagamento de um décimo quarto salário a todo o quadro de funcionários da escola cujo desempenho alcance as metas definidas pelo governo municipal. Ou seja, um percentual alto de estudantes tem que ser aprovado para que todos os trabalhadores da escola ganhem uma remuneração não prevista no contrato.

De acordo com Foucault o bom pastor não pode pensar em lucros próprios e sim ter uma conduta de autosacrifício em prol de seu rebanho. Assim, a aplicação dessa bonificação em retorno ao cumprimento de metas estaria promovendo sentimentos corruptíveis no meio do grupo docente que aceita "desviar" sua conduta, prejudicando seu rebanho, em beneficio próprio? Seria contra o ideal de professor/pastor que dita que é preciso reger seus alunos/ ovelhas sem nenhuma ideia de fundo "egoísta", já que a preocupação do pastor nunca é com ele próprio e sim com suas ovelhas, baseado no fardo de guiá-las?

O mau pastor é aquele que só pensa no pasto para seu próprio lucro, que só pensa no pasto para engordar o rebanho que poderá vender e dispensar, enquanto o bom pastor só pensa no seu rebanho e em nada além dele. Não busca nem seu proveito próprio no bem-estar do rebanho (FOUCAULT, 2008, p. 170).

De acordo com as falas dos participantes do curso, a cobrança que a escola exerce sobre o professor, exigindo-lhe que alcance índices pré-estabelecidos, o coloca em uma situação conflitiva. Tais exigências impossibilitariam a conduta pastoral do professor. Ou seja, há uma idealização do "papel"10 do professor, ancorada na lógica do pastorado: o professor/pastor deveria ser um exemplo moral para seus alunos/ovelhas, deveria ter o poder sobre elas, corrigindo-as e instruindoas para que sejam capazes de seguir o "caminho correto". Contudo, para cumprir tais metas o professor tem que se encontrar com a sua condição de trabalhador assalariado, atravessada tanto por seus ideais morais, quanto pelas determinações econômicas e políticas. A idealização de um professor/pastor como guia espiritual é posta em questão, colocando em xeque a sua atuação pedagógica e uma sensação de ter-se corrompido.

Não só a relação financeira produz o que é vivido como corrupção ao bom pastor, mas a descrença na proposta pedagógica como redentora torna-se patente. Pouco se fala das propostas e dos resultados conteudistas, centrando o discurso pedagógico na relação comportamental de estudantes e trabalhadores. Talvez, se o que justifica uma nota - o conteúdo - fosse o pilar do trabalho docente, seria mais intenso e aberto o debate sobre a decisão de remunerar os professores em função da aprovação dos estudantes. Quando a aprovação deixa

\footnotetext{
${ }^{9}$ IDEB é o Índice de Desenvolvimento da Educação Básica, criado em 2007, com o objetivo de medir a qualidade do aprendizado a nível nacional e desenvolver metas visando a melhoria do ensino.

${ }^{10}$ Utilizamos o conceito de papel para indicar uma ideia positiva universalizante que compreende apenas uma forma identitária de ser professor.
}

de justificar-se pelo domínio de um conteúdo e passa a ser definida por dinheiro, o governo da cidade do Rio de Janeiro faz economia garantindo que os estudantes não reprovem e saiam antes da escola, sabendo que não interfere na relação curricular. Os conteúdos, o que em tese é avaliado na escola, não faz sentido para os professores, que podem negociar notas por renda. É um lugar comum dizer que os estudantes querem notas para passar, sem importar-se com os conteúdos. Mas pouco ou nada fala-se do interesse ou da preocupação dos professores em relação à assimilação de seus ensinamentos, pois a centralidade do discurso pedagógico está no comportamento, na obediência às regras e na aferição de uma nota aprovatória. Embora a assimilação do conteúdo não tenha sido uma preocupação visível no diálogo com os professores, ao se verem motivados a obedecer um padrão de avaliação em benefício próprio manifestam um sentimento de corrupção. Um sistema sustentado na normalização sob a lógica pastoral tampouco discute o interesse dos estudantes e o quanto absorvem dos conteúdos acadêmicos, mas a obediência à norma. A figura do pastor expressa bem a atmosfera angustiante que vivencia a vida docente quando a norma orientase a interesses apresentados como particulares, porque destituídos de uma discussão em que estão atravessados os sentidos pedagógico, político e trabalhista.

Não se constroem estratégias para suprir conteúdos, pois inclusive sabe-se que passar uma prova não quer dizer ter domínio deles. Estas questões podem estar presentes no pensamento de uma professora que discute a possibilidade de alterar o conceito avaliativo de um estudante, quando o colegiado considera que ele não deveria repetir o ano escolar cursado para que a escola alcance a meta e ganhe o bônus:

\section{[...] Tudo bem. Mas aí nós estamos ensinando aos alunos que em determinados momentos nós podemos fazer, forjar determinados documentos, porque o aluno sabe que ele não é bem formado, ele sabe, mas se amanhã ele fizer isso [forjar uma nota que não foi atribuída pelo professor] ele vai parar na cadeia [...] A gente produz os alunos e a gente pune os alunos amanhã. Isso é o que a gente faz (Professora 5).}

Com a definição das notas (avaliações numéricas) construídas por meio de provas, da disciplinarização e de uma rígida hierarquia, visualizamos na fala dos professores uma preocupação com a imagem de si mesmos e com as referências morais que passam para seus estudantes. Há resistências e aceitação. O professor apresenta-se como uma figura desgastada, conformada com o seu sacerdócio, mesmo quando não acredita no discurso conteudista da escola, mantendo a crença de ser ele quem pode construir pessoas aptas a "seguir caminho". Por meio da disciplinarização, da docilização dos corpos, da crença e do trabalho minucioso e individual é que o poder pastoral se afirma no magistério.

Os alunos estão acordados, os professores também estão acordados. E é muito difícil [....] Eu tenho turmas que rolam as regras, ai eu fui chamado na Secretaria de Educação e tive que burlar normas. Impossivel que uma turma seja homogênea, se a gente tá ali pra trabalhar 
isso [a singularidade de cada estudante], lógico que tem as diferenças, e eu realmente tive que burlar, inventar nota, pra bater meta, porque o Rio de Janeiro ficou em penúltimo em 2010, do IDEB, então é uma pressão muito grande [...] (Professor 1).

É perceptível a preocupação dos professores em seguir normas, regras e transmitir as mesmas para os discentes. De um lado os professores têm o dever de segui-las, mas de outro, o fazem acreditando que a regra, a norma é fundamental ao funcionamento pedagógico e não só a seguem, mas fazem todos acreditar nelas. Para atender suas próprias expectativas de professor/pastor estes buscam meios disciplinares, controlam a frequência em aula, a participação do aluno, aplicam as avaliações e acreditam que com isso estarão colaborando com, ou guiando, a "boa formação" dos estudantes. Porém, ao serem pressionados para o cumprimento de metas, os professores percebem a fragilidade tanto de palavras de ordem que pautam a sua prática profissional, quanto das bases nas que construíram a sua relação com os estudantes, elevando conceitos por motivos que não condizem com o discurso conteudista, o que é interpretado como um conceito sem merecimento.

Outro elemento que nos ajuda a entender os efeitos da lógica de metas é a relação com a perícia no fazer docente. A nuance entre a lógica do pastorado e a de metas está presente no atravessamento de elementos como a perícia e a meritocracia na prática docente. Em A cultura do novo capitalismo, Sennett (2006, p. 98) afirma que a perícia "é uma palavra aplicada quase sempre a trabalhadores manuais, denotando a busca da qualidade na fabricação [...]", indicando fazer algo pelo desejo ou prazer, fazê-lo da melhor forma possível. O trabalho realizado com perícia "é feito por sua própria importância" (SENNETT, 2006, p. 99), fazendo com que o trabalhador tenha orgulho do que produziu, mesmo que seja pouco valorizado por isso.

Entretanto, na conjuntura de uma economia liberal de mercado como a nossa, que exige cada vez mais a flexibilidade dos trabalhadores que nela atuam, a perícia se torna, em muitos casos, um elemento mal visto, já que o comprometimento com a prática do bem fazer é inconciliável com rotinas flexíveis de trabalho. Por isso, Sennett afirma que por volta dos séculos XVII e XVIII temos a passagem da perícia para a meritocracia, quando a instituição militar passou a relevar o talento como requisito para a ascensão. Uma conduta tipicamente meritocrática, pois mais que reconhecer os talentos são exaltados os fracassos para demarcar a hierarquia.

Por meio de procedimentos burocráticos se percebe o íntimo do indivíduo, avalia-se a aptidão e punemse os fracassados ou inaptos. O autor afirma: "[...] a meritocracia transforma o espírito de perícia numa comparação invejosa e altamente pessoal" (SENNETT, 2006, p. 105). Aos poucos, essa lógica meritocrática, que opera por meio de uma maquinaria burocrática, passa a atravessar as áreas da medicina, do direito e da educação.

Fractal, Rev. Psicol., v. 28 - n. 3, p. 370-378, 2016
Ao pensar a prática docente na sociedade contemporânea que burocratiza o talento, podemos compreender as metas estipuladas pelo município do Rio de Janeiro como um instrumento que visa avaliar a aptidão dos professores para fazer os estudantes atingirem os conceitos estipulados com a pretensão de quantificar a aprendizagem do discente.

Essa cobrança que recai sobre o professor, lhe impede de operar como um pastor, justamente porque a atividade pastoral requer certa perícia para com o trato das ovelhas. O pastor tem um trabalho árduo ao dedicar-se a cada membro do seu rebanho. Um trabalho que requer da obsessão pelo bem fazer e, por isso, encontra-se deslocado em relação à exigência do capitalismo. A fala angustiada de um estudante universitário que dá aulas de história como estagiário denota tal conflito:

Eu tenho certeza, porque mesmo com a problemática de você ter que ter um score, de você ter que ter e apresentar um ranking [...] [com] uma nota forjada, eu quero fazer o meu melhor pra produzir um cidadão, que eu entendo que vai contribuir pra sociedade (Estagiário 1).

O que vemos são práticas que operam por lógicas diferentes. Não há, do nosso ponto de vista, uma infração ou traição a um ideal, mas um atravessamento de lógicas. Do ponto de vista da moral pastoral há sim uma ruptura de confiança; do ponto de vista sócio-histórico há uma construção de sentidos que difere daquela que vem sustentando a relação dos discentes e docentes com a escola. De acordo com a fala do Professor 1 "os alunos estão acordados", dando-se conta da inconsistência de regras apresentadas como um ideal moral, e identificando esse processo vivido pelos trabalhadores da escola e pelas famílias como corrupto, por pautar-se no desejo de alcançar metas que garantem uma renda melhor, o que não é entendido como condição para o trabalho docente.

Sob uma concepção do trabalho pedagógico como prática moral, querer ter uma renda melhor torna-se uma vergonha. Não se trata de aceitar qualquer prática profissional em troca de dinheiro, mas tampouco de achar que a renda é secundária no trabalho remunerado, no caso, o trabalho docente: "E isso me entristece muito porque eu, por exemplo, como historiador, eu como professor de História, tenho visto a colega falar sobre isso, da vocação, é quase um sacerdócio, mas eu tenho gente pra alimentar" (Estagiário 1).

Alguns professores relataram experiências vividas nos conselhos de classe, ${ }^{11}$ questionando os professores que não cumpriram com os índices:

[...] Teve um conselho de classe que a coordenadora chegava e falava: - "Você vai ter que melhorar a nota", e todo mundo caiu em cima da colega [que atribuiu notas baixas]: "Só a sua turma não alcançou a meta". Ela [a professora] foi ótima na atitude, eu apoiei: - "É, então tá, MB pra todo mundo: MB". Ela alcançou a meta, eles [a equipe da escola] ganharam conceito A [...] (Professora 1).

${ }^{11}$ Conselho de classe é uma reunião da equipe pedagógica da escola que define as notas dos estudantes. Em geral comparecem ao conselho de classe professores, orientadores, coordenadores, diretores e, em algumas ocasiões, conta também com a participação de estudantes. 
De acordo com esta participante do curso, a própria direção pressionou a professora: "Então não vamos ganhar. Dá um jeito! Da um jeito!"'(Professora 1). Vemos nessa narrativa o questionamento feito pela direção e pelo corpo docente ao fato de uma turma ser a única a não atingir o conceito necessário à meta que daria melhor renda aos trabalhadores da escola. A professora só tinha como opção, no fim do ano escolar, alterar o conceito, mas para fazê-lo opta por dar para toda a turma a nota máxima: MB. A professora que contou o fato diz que apoiou a atitude da colega e coloca sua prática docente em análise: ela estaria sendo uma professora capaz de realizar o que crê ser uma prática docente coerente? Este questionamento, geralmente sem uma resposta, vem se apresentando como uma das crises que estaria adoecendo, reduzindo o prazer profissional e tornando a profissão docente sem sentido.

De acordo com outro participante do curso, a necessidade de forjar conceitos, exigida pela direção das escolas para o alcance das metas, tem criado para o professor uma situação de impotência perante o corpo discente. A nota, que é um dos mecanismos do qual faz uso o poder disciplinar, concede ao professor um domínio hierárquico perante a turma. Quando o professor perde autonomia no processo avaliativo, sente-se fragilizado ou, nas palavras do Estagiário 1, torna-se um "refém":

[...] a gente vê o professor, tentando realmente forjar uma situação que não existe dentro da sala de aula. Eu como estagiário de EJA, observo que alguns alunos não conseguem conteúdo conceitual daquele período. E essa situação do IDEB, que você coloca acima da realidade, você faz com que o aluno ache que tem poder sobre o professor, que tem certa ingerência no professor e de certa forma torna o professor refém da sua ação [....] O que eu tenho visto, o que eu vejo como prática, é uma situação muito ruim, uma situação de coação ao professor, ele tá acuado, ele tá colocado no canto da parede, e ele tem que apresentar uma produtividade que não é verdadeira, e isso tem tornado ele refém dos aluno (Estagiário 1).

Certamente, esta fala coloca em pauta, entre outras questões, a nota como elemento central da estrutura pedagógica disciplinar, por sua potência coativa. Ao ter que forjar nota, o professor considera que não resta muito em sua relação pedagógica, por perder a sustentação da sua hierarquia. A idealização do professor/pastor é sustentada em uma hierarquia que, por sua vez, se sustenta na avaliação quantitativa. O poder de definir uma nota tem dado suporte ao controle sobre estudantes e familiares. A perda deste instrumento é o enfraquecimento do pastor perante o seu rebanho. Rebanho que agora que não está atado ao pastor se locomove segundo sua própria vontade, ignorando as ordens daquele que deveria conduzi-lo. O pastor se encontra diminuído e incapaz de bem conduzir seu oviário.

Dada tal situação, o pastor encontra-se deslocado de sua posição de costume. Em face disso, vemos por um lado a eclosão de resistências: alguns professores tentam encontrar outros caminhos, outras formas, alguns escapes. Por outro lado, percebemos que, forçados a lidar com os parâmetros avaliativos exigidos, os professores percebem a si mesmos capturados por uma estrutura normativa, proveniente de um rígido sistema disciplinar: "Você de alguma forma se enquadrou, se não você não estaria na escola. Eu me pergunto isso o tempo todo: - Como? E já tô, com certeza. Já fui costurada" (Professora 1).

\section{Referências}

Deleuze, G; GUATTARI, F. Mil Platôs: capitalismo e esquizofrenia. Tradução de Aurélio Guerra Neto e Célia Pinto Costa. São Paulo: Editora 34, 1995. v. 1.

FOUCAULT, M. Vigiar e Punir. Petrópolis, RJ: Vozes, 1987.

FOUCAULT, M. Segurança, Território e População. São Paulo: Martins Fontes, 2008.

GUATTARI, F.; ROLNIK, S. Micropolitica: cartografias do desejo. 4. ed. Petrópolis, RJ: Vozes, 1996.

SENNETT, R. A cultura do novo capitalismo. Rio de Janeiro: Record, 2006.

SENNETT, R. A corrosão do caráter: as consequências pessoais do trabalho no novo capitalismo. 14. ed. Rio de Janeiro: Record, 2009.

ZIRALDO. Uma professora muito maluquinha. 16. ed. São Paulo: Companhia Melhoramentos, 1995.

Recebido em: 28 de abril de 2015 Aceito em: 14 de novembro de 2016 